\title{
Human Rights of Journalists Working in Kashmir: An In-depth Analysis
}

\author{
Sahil Koul*
}

ABSTRACT

\begin{abstract}
Media/ press have always played a role of a watchdog, highlighting the human rights violation of masses. But who takes the charge when human rights of media professionals are violated? When it comes to Kashmir which has been a conflict area since early 90 's, there have been many cases where journalists have lost their lives while performing their duties. There have been number of cases when copies of newspapers have been prevented from distribution and publications have been forced to stop. During the July 2016 unrest in Kashmir (after the killing of Burhan Wani) curfew was imposed in entire valley wherein journalists were not allowed to move and perform their duties. One of the newspapers Kashmir Reader was banned for months. This paper strives to find out the media environment and state of human right of journalists working in Kashmir.
\end{abstract}

Keywords:Human Rights of Journalists, Media Environment, Media Censorship, Violence against Media.

\section{Introduction:}

Media or press is considered as the fourth estate of the democracy and it acts as a watchdog over the other three estates i.e., legislative, executive and judiciary. Media has been bestowed with such a large responsibility which can only be shouldered with fair and accurate reporting. While performing their duty, the media professionals face many challenges ranging from harassment, curtailment of freedom of speech and expression and at times threat to life.

According to the 'Round Up Report' for the year 2017 of Reporters Without Border updated on 25th December 2017, 52 journalists, 7 citizen journalists and 8 media assistants have been killed worldwide in connection with their work and India is ranked 136 out of 180 surveyed Countries. (Violations of press freedom barometer, 2017). When we talk about reporting in a state like Jammu and Kashmir which has been a conflict area for more than 26 years, the authorities must make extra efforts to ensure the safety of the rights of the media professionals as the chances of violation of these rights are more than in any non-conflict area. Around a dozen journalists have been killed in Jammu and Kashmir since the insurgency began starting with the killing of Lassa Kaul, Director Doordarshan who was killed by militants on his way home on Feb 13, 1990.(Khalid, 2012) Many journalists were abducted by the army and militant outfits and imposition of restriction on free movement of

\footnotetext{
Assistant Professor,VSJMC, Vivekananda Institute of Professional Studies, GGSIP University, New Delhi, Senior Research Scholar, School of Communication Studies,Panjab University, Chandigarh.
}

journalists has been observed a number of times. Besides restriction on freedom of speech and expression, journalists continued to encounter physical harassment and verbal suggestions or written directives from the government or militant groups to slant coverage a certain way.(India | Country report | Freedom of the Press | 2013, 2013)

On $8^{\text {th }}$ July 2016 when a separatist military commander, Burhan Wani, was killed in south Kashmir following which protest broke out in Kashmir, "Around 45 civilians were killed and more than 1,600 were injured. On 15th July, police raided the offices and printing plants of newspapers like Kashmir Times, Greater Kashmir, Kashmir Observer and Rising Kashmir and seized a large number of printed copies. During the raids, 50,000 copies of the daily Kashmir Uzma were also seized." (RSF condemns Kashmir media blackout by Indian authorities | RSF, 2016). Condemning the raids on media housed and their printing presses, the Editors Guild of India president Raj Chengappa, general secretary Prakash Dube and treasurer Seema Mustafa said, "The Editors Guild of India strongly condemns the efforts by the Jammu and Kashmir government to gag the media in the state... It is extremely unfortunate that the state government, under fire for its poor management of the law and order situation in the Valley, has sought to shoot the messenger."(Editors Guild slams 'muzzling of media' in Kashmir | The Indian Express, 2016). What can be worse than detaining the journalists on World Press Freedom Day? Police detained a few journalists in Srinagar on the World Press Freedom Day on Tuesday May 3 2016 when they staged a demonstration against the government's new advertisement policy.(Now, 
2016).During the communal riot in the Kishtwar district of Jammu and Kashmir which in the year 2013, after the riots began, the first thing that the state government did was prevent the publication of newspapers, stopped news channels from broadcasting the news and discontinued the internet facility in the state.(Chatterji, 2013). Same steps were taken when Afzal Guru, the 2001 parliament attack convict was hanged in Tihar jail on February 9, 2013. The media in Kashmir was prevented from publishing, TV and Radio were taken off air and internet facility were discontinued.(Mustafa, 2013)

On February 4, 2013, Press Council of India (PCI) Chairperson, MarkandeyKatju reacting to the alleged stopping of advertisement to publications by state governments over critical articles against government carried by them said, "PCI will not tolerate such behavior and shall take suitable legal action. Stopping advertisements or drastically reducing them merely because a critical article has been published, is totally undemocratic and shows pettiness of mind, and is totally unacceptable in a democracy. Such actions infringe on Freedom of Speech. Newspapers and journals must be a given a hearing by issuing them show cause notice if the concerned authorities decide to curtail advertisements to them. I have been receiving several complaints from newspapers and journals that the advertisements which were being issued to them by central or state governments have at times suddenly stopped or drastically reduced without assigning any reason. Sometimes this is done because of the newspapers/ journals publishing material critical of a government or some of its ministers/officials. Advertisements are the main form of revenue for newspapers and journals and such actions violated Press freedom."(Govt can't blackmail media with advertisements: Justice Markandey Katju - Times of India, 2013). The above sited instances highlight the status of human rights of journalists working in Kashmir.

\section{Objectives:}

1. To understand the status of human rights of journalists working in Kashmir.

2. To identify the types of violations of human rights of journalists if any in Kashmir.

3. To investigate the judicial, business and administrative pressures on journalists working in Kashmir.

\section{Methodology:}

In-depth Interview of four accredited and senior journalists was conducted for the study as the sensitive nature of the data suggested that the indepth interviews might be most appropriate for this study. The list of accredited journalists is available on the website of department of Information and Public Relation Jammu and Kashmir. The four Journalists were chosen randomly from the list with the help of the website www.random.org.

A structured in-depth interview was conducted wherein all the responses were recorded with the help of an audio recorder. The results were analyzed using Constant Comparative Technique of qualitative data analysis. The process consists of four steps:

1. Comparative assignment of incidents to categories

2. Elaboration and refinement of categories

3. Searching for relationships and themes among the categories

4. Simplifying and integrating data into a coherent theoretical structure.

\section{Data analysis and interpretation}

Constant comparative technique was used to analyze the data. The technique was first articulated by Glaser and Strauss in 1967 and has been subsequently refined by Lincoln and Guba in 1985. The process consists of four steps:

The broad themes that emerged from the data analysis of four in-depth interviews conducted are:

\begin{tabular}{|l|l|}
\hline Category & $\begin{array}{l}\text { Questions falling in the } \\
\text { category }\end{array}$ \\
\hline $\begin{array}{l}\text { Media } \\
\text { environment }\end{array}$ & $\begin{array}{l}\text { Q. Do you think media } \\
\text { environment in Jammu and } \\
\text { Kashmir is positive towards } \\
\text { human rights of the } \\
\text { journalists? } \\
\text { Q. Are there privately-owned } \\
\text { TV and Radio stations and if } \\
\text { yes, are they free to determine } \\
\text { their editorial policies? } \\
\text { Q. What about state owned } \\
\text { media DD and AIR, does the } \\
\text { government control their } \\
\text { editorial policies? }\end{array}$ \\
\hline Media \\
censorship & $\begin{array}{l}\text { Q. Have you ever experienced } \\
\text { any form of censorship } \\
\text { including hesitation on your } \\
\text { part to publish or cover } \\
\text { certain article? }\end{array}$ \\
\hline
\end{tabular}




\begin{tabular}{|l|l|}
\hline $\begin{array}{l}\text { Violence and } \\
\text { abusive } \\
\text { treatment } \\
\text { journalists }\end{array}$ & $\begin{array}{l}\text { Q. In your experience as a } \\
\text { journalist have you ever } \\
\text { witnessed any abusive } \\
\text { treatment to yourself or your } \\
\text { colleagues or fellow } \\
\text { journalists? }\end{array}$ \\
\hline $\begin{array}{l}\text { Media } \\
\text { Legislation }\end{array}$ & $\begin{array}{l}\text { Q. Do you think there are } \\
\text { legal provisions that } \\
\text { safeguard the human rights of } \\
\text { journalists working here or } \\
\text { should there be any specific } \\
\text { law? there there freedom of } \\
\text { Q. Is there } \\
\text { information law or RTI act } \\
\text { and does it make it easier for } \\
\text { you to gain access to } \\
\text { information? }\end{array}$ \\
\hline $\begin{array}{l}\text { State a. Do you think state is also } \\
\text { responsibility } \\
\text { in abusive } \\
\text { treatment } \\
\text { journalists }\end{array}$ & $\begin{array}{l}\text { of } \\
\text { responsible for the abuses } \\
\text { against the media } \\
\text { professionals? }\end{array}$ \\
\hline $\begin{array}{l}\text { State's role in } \\
\text { combating } \\
\text { impunity for } \\
\text { those } \\
\text { responsible for } \\
\text { violence and } \\
\text { abuses }\end{array}$ & $\begin{array}{l}\text { Q. Do the authorities try to } \\
\text { punish those responsible for } \\
\text { the abuses or violence against } \\
\text { media persons? }\end{array}$ \\
$\begin{array}{l}\text { Judicial, } \\
\text { business and } \\
\text { administrative } \\
\text { pressures }\end{array}$ & $\begin{array}{l}\text { Q. Are the journalists aware } \\
\text { about the judicial, } \\
\text { administration and political } \\
\text { pressures? }\end{array}$ \\
\hline $\begin{array}{l}\text { Internet and } \\
\text { new media }\end{array}$ & $\begin{array}{l}\text { Q. Have the authorities } \\
\text { exercised direct or in direct } \\
\text { control over the internet? }\end{array}$ \\
\hline
\end{tabular}

\section{Media Environment}

The journalists working in Kashmir believe that since Kashmir is a conflict zone, the journalists have to be cautious while covering stories as some of the stake holders might not like the way in which a particular story is covered. The journalists believe that they were not able to work freely particularly in the year 2016. Most of the unrest and violence following the killing of Burhan Wani took place in south Kashmir and all the media organizations are majorly located in Srinagar and could not reach south Kashmir as curfew was imposed and media professionals were not allowed to move. The journalists believe that although the state has enormous talent and the newspaper strength has grown manifolds in past 26 years, the state has failed in institutionalizing journalism in Kashmir. The journalists believe that they are continuously working under pressure both direct and indirect from different agencies. They revealed that the journalists have seen very tough times working in Kashmir as 13 of their colleagues have lost their lives and many journalists have been either jailed, harassed, intimidated or beaten up. They further revealed that there are no privately-owned TV and Radio stations that broadcast news whileDoordarshan and All India Radio despite being public broadcasters are totally controlled by the government and always toe the line and propagate government side more than highlighting what is happening on the ground.

\section{Media Censorship}

The journalists working in Kashmir believe that media censorship exists in Kashmir as many newspaper organizations have been raided by the authorities and there was a blatant ban on Kashmir Reader newspaper following the 2016 unrest that lasted for months. The journalists believed that no journalists will claim that he has not been restricted from doing something either officially or unofficially or no journalist will claim that he has not resorted to self-censorship. Most of the journalists still believed that they have done their job professionally even under very testing circumstances as they have always ensured to get the other side of the story as well. However, photojournalists have always worked under more restrictions.

\section{Violence and Abusive Treatment of Journalists}

The journalists interviewed revealed that they face a lot of violence and abusive treatment and they have been beaten up, intimidated, harassed, their cameras are broken and at times they are slapped with Public Safety Act. One of the journalists said that he has survived three assassination attempts besides being threatened and intimidated by both government and militants. The journalists working in Kashmir believe that their curfew passes are not honoured by the forces and they are not allowed to reach to the victims or to a particular spot to cover a story. The journalists revealed that the abusive treatment and violence has been part of their lives.

\section{Media Legislation}

Talking about the laws that safeguard the human rights of journalists, the interviewees revealed that the legal provisions are there, but they are not implemented in Kashmir. They believe that there are only two newspapers where the employees are protected under the labor law. The journalists believe that the security forces need training regarding how to deal with the journalists as they see journalists as a threat and not as a messenger. One of the interviewee said 
that journalists working in Kashmir also need to be trained about how to work in a conflict zone. The journalists believe that the information sought through Right to Information act is usually delayed and denied in most of the cases under the garb of national security and defense. However, some journalists believe that RTI was still evolving in the state and journalists need to be sensitized to an extent as to how beneficial it could be for them. The journalists believe that there was no requirement of new laws as far as their human rights are concerned but just the implementation of already existing laws is needed.

\section{State responsibility in abusive treatment of journalists}

The interviewees believe that the state has been responsible for the abusive treatment to the journalists working in Kashmir as many journalists have been beaten up number of times. The journalists revealed that there are both visible and invisible pressures. Invisible pressures like journalists receive messages from different people asking why a particular story was covered and, in such situations, not everything is made public and eventually the journalist succumbs to the pressure. They believe that their phones are being tapped by the police and other government agencies and they are under constant surveillance. The journalists apprised that in 2010 there were restrictions, journalists were harassed and intimidated and newspapers were not allowed to publish for 15 days. The interviewees believe that the authorities curtail their movement whenever there is a shut down and do not honour the curfew passes issued to them when curfew is imposed. The journalists believe that the authorities allow only selected news channels especially the ones from New Delhi to cover stories as they highlight only one side of the story and toe the government line. Citing the examples of recent unrest in July 2016, the journalists revealed that a local newspaper Kashmir Reader was banned for months without revealing the reasons which was condemned by the Editors Guild of India as well. During the same unrest two of the photojournalists also received pellet gun injuries in their eyes. They believe that journalists are summoned to the police station, arrested at times and in extreme cases slapped with Public Safety Act that is imprisoned without trial.

\section{State's Role in Combating Impunity for those} Responsible for Violence and Abuses

When asked whether the authorities try to punish those responsible for the abuses or violence against media persons, the interviewees informed that there is no action is such cases and at the most they are given assurances that a strong note has been taken against those who are involved in the abuses. However, some of the journalists opined that there is an effort by the state to defend those who are responsible for such actions and in some case the violators are even promoted and given good postings.

\section{Judicial, Business and Administrative Pressures}

The interviewees believe that the journalists working in Kashmir are facing all sorts of pressures. The journalists said that it is unfortunate that the newspaper offices are raided, and the copies are seized by the authorities. The journalists said at times they are dictated what to cover and what not to. Banning of newspapers like Kashmir Reader is a warning to all other newspapers that if they do not toe the government line they will face the same consequences. The interviewees further believe that the withdrawal of DAVP advertisements is a major tactic employed by the authorities to pressurize the media and organizations like Rising Kashmir, Kashmir Times and Greater Kashmir are bearing that brunt from last six years. The state government advertisement is also banned at times by the Department of Information and Public Relations.

\section{Internet and New Media}

The journalists believe that the authorities have exercised direct control over the internet services in Kashmir. The journalists revealed that during the 2016 unrest, mobile internet was banned for four months and then broadband and other internet services were also stopped. The interviewees revealed that for the first three days of the unrest there was no internet at all and after a protest from the media fraternity, the broadband services of the government owned BSNL were resumed. The journalists apprised that they faced lots of problems during this time as even mobile phones and short message services (SMS) were also banned and the reporters had to use landline phones for covering and filing the stories. The Journalists mentioned that stopping internet service is nothing new to them as it has been happening in the past as well whenever there is any law and order situation however they opined that banning internet and mobile phone services lead to even worst law and order situation as people are misinformed in the absence of functional media. 


\section{Discussion and Conclusion}

This paper has attempted to describe the Status of human rights of the journalists working in Kashmir, focusing on issues like media legislation, violence and abuses against journalists and censorship.

The study reveals that the journalists believe that the authorities indulge in censorship by way of preventing the publication, seizure of issues of newspapers and controlling the communication medium like the internet and telephones. It is interesting to note that the UNESCO's 1979 report on 'Means of enabling active participation in the Communication process and analysis of the right to communicate' mentions, "The changing world situation is bringing about profound changes in human communication. These changes are leading to new and enlarged perspectives. A strong relationship between human communication needs, the development of communication resources and human rights becomes evident. This relationship may be stated in the following way: mankind has the right to communication resources required to satisfy human communication needs." (UNESCO 1976: 7)

Article 19 of the Universal Declaration of Human Rights (UDHR) states, "Everyone has the right to freedom of opinion and expression; this right includes freedom to hold opinions without interference and to seek, receive and impart information and ideas through any media and regardless of frontiers. Likewise, the fundamental rights of the Indian Constitution provide for, under Article 19 (1) (a), 'All citizens should have right to freedom of speech and expression.' This right is extended to the press as well.

The McBride Commissions report states, "Everyone has the right to communicate: the components of this comprehensive human right include but are not limited to the following specific communication rights: (a) a right to assemble, a right to discuss, a right to participate and related association rights; (b) a right to inquire, a right to be informed, a right to inform and related information rights; and (c) a right to a culture, a right to choose, a right to privacy and related human development rights (...) The achievement of a right to communicate would require that communication resources be available for the satisfaction of human communication needs. "We suggest that this approach promises to advance the democratization of communication on all levelsinternational, national, local, individual. (MacBride, 1980: 173)
The present study reveals that the journalists working in Kashmir believe that there is no freedom of information law in Kashmir as the present laws like the right to information act; do not make it easier for them to access the officially held information. The interviewees emphasize that the authorities use withdrawal of advertisement to curb the right to freedom of speech and expression of media. The journalists further stated that the laws are not implemented on ground.

Article 5 of the UDHR states that no one shall be subjected to torture or cruel, inhuman or degrading treatment or punishment, Article 9 of UDHR states that no one shall be subjected to arbitrary arrest, detention or exile while Article 13 of UDHR provides for right to freedom of movement and residence within the borders of every state. All these rights are also guaranteed by the Indian constitution under the fundamental rights (Article 12-35).

However, the study reveals that the journalists working in Kashmir believe that there are abused, beaten up and harassed. They have many times faced restriction in movement, seizures of copies of newspapers, searches and interrogations.

\section{References:}

Chatterji, R. (2013, AUGUST 13). Kishtwar live: Omar, BJP continue blame game as issue rocks Parl. Retrieved JUNE 5, 2014, from First post India.:

http:/ / www.firstpost.com/india/kishtwarlive-omar-bjp-continue-blame-game-asissue-rocks-parl-1024775.html

Editors Guild slams 'muzzling of media' in Kashmir | The Indian Express. (2016, July 18). Retrieved July 25, 2016, from The Indian Express: http://indianexpress.com/article/india/ind ia-news-india/editors-guild-slamsmuzzling-of-media-in-kashmir-2920287/

Govt can't blackmail media with advertisements: Justice Markandey Katju - Times of India. (2013, February 5). Retrieved December 10, 2013, from The Time of India: http:/ / timesofindia.indiatimes.com/india/g ovt-cant-blackmail-media-withadvertisements-justice-markandeykatju/articleshow/18341000.cms

India | Country report | Freedom of the Press | 2013. (2013). Retrieved February 25, 2014, from Freedom House: https:/ / freedomhouse.org/report/freedompress/2013/india 
Khalid, W. (2012, January 7). Eleven Killings in Kashmir Journalism. Retrieved June 14, 2014, from The Kashmir Walla: http:/ / www.thekashmirwalla.com/2012/01 /eleven-killings-in-kashmir-journalism/

Mustafa, S. (2013, Feberuary 28). Playing 'hard state'. Retrieved June 5, 2014, from The Hindu:

http:/ / www.hindu.com/fline/fl3004/storie s/20130308300402100.htm

Now, J. (2016, May 3). Journalists detained in Kashmir on world press freedom day. Retrieved from Jandk Now: http://www.jandknow.com/news/exclusiv e/050316382-journalists-detained-kashmirworld-press-freedom-day

RSF condemns Kashmir media blackout by Indian authorities | RSF. (2016, July 21). Retrieved December 10, 2016, from Reporters Without Border: $\quad$ https://rsf.org/en/news/rsfcondemns-kashmir-media-blackout-indianauthorities

Violations of press freedom barometer. (2017, December 25). Retrieved December 25, 2017, from Reporters Without Border: https://rsf.org/en/barometer 